\title{
Morphological and Anatomical Analyses of the Serpentine Ecotype of Adenophora triphylla var. japonica (Campanulaceae)
}

\author{
Kyohei Ohga ${ }^{1}$, Miwako Muroi ${ }^{1}$, Hiroshi Hayakawa ${ }^{2}$, Jun Yokoyama ${ }^{3}$, Katsura Ito $^{2}$, Shin-ichi Tebayashi ${ }^{2}$, Ryo \\ Arakawa $^{2} \&$ Tatsuya Fukuda $^{2}$ \\ ${ }^{1}$ Graduate School of Integrated Arts and Sciences, Kochi University, Nankoku, Japan \\ ${ }^{2}$ Faculty of Agriculture, Kochi University, Nankoku, Japan \\ ${ }^{3}$ Faculty of Science, Yamagata University, Kojirakawa, Japan \\ Correspondence: Tatsuya Fukuda, Faculty of Agriculture, Kochi University, Nankoku, Japan. Tel: \\ 81-888-645-140. E-mail: tfukuda@kochi-u.ac.jp
}

Received: June 25, 2012 Accepted: August 27, 2012 Online Published: September 1, 2012

doi:10.5539/jps.v1n2p180 URL: http://dx.doi.org/10.5539/jps.v1n2p180

\begin{abstract}
The morphological and anatomical analyses of leaves in the serpentine ecotype of Adenophora triphylla var. japonica (Regel) H. Hara were carried out. In comparison to the normal type of this variety, the serpentine ecotype has a narrower leaf due to decrease in the number and size of cells. The stenophyllization process of the serpentine ecotype is similar to that of the rheophytic ecotype. The study further indicates that the decreased number and size of cells is a general tendency in stenophyllization. By contrast, leaf thickness and stomatal density of the serpentine ecotype differed significantly from those of the rheophytic ecotype, suggesting that the two ecotypes are differently adapted to solar radiation and evaporation.
\end{abstract}

Keywords: Adenophora triphylla var. japonica, serpentine, stenophyllization

\section{Introduction}

Most plants evolved from pre-existing taxa as populations adapt to local conditions. Although this topic has been extensively researched (Kruckeberg, 1951, 1954, 1967; Rajakaruna et al., 2003; Wright et al., 2006), the mechanisms of plant edaphic adaptation are not fully understood. Serpentine (ultramafic) soils provide an exceptional system for studying edaphic adaptation, because plant adaptation to them is widespread geographically and phylogenetically and involves similar tolerances to unique edaphic factors (Brady et al., 2005). Serpentine soils are characterized by high (potentially toxic) concentrations of $\mathrm{Ni}$ and $\mathrm{Mg}$, low concentrations of plant nutritional elements, and a low Ca: Mg ratio (Brady et al., 2005). In addition, they are dry because of their granular texture. Although a range of chemical and physical factors influence plant growth, high Ni concentrations and a abnormal Ca: Mg ratio are considered to be crucial for plant survival (Brady et al., 2005). Serpentine soils are associated with a unique vegetation, which is sparse and often includes a high proportion of endemics (Kruckeberg, 1954). Thus, serpentine floras provide an excellent opportunity to examine mechanisms of endemism that have evolved to withstand heavy metals (Kruckeberg, 1954; Brady et al., 2005).

A number of plants have adapted to the serpentine environments of Japan. Most of these species have morphological characteristics such as narrower leaves and thinner stems. For example, Hayakawa et al. (2012) demonstrated that the narrow leaf of the serpentine endemic Aster hispidus Thunb. var. leptocladus (Makino) Mot.Ito was associated with a decreased cell number in the horizontal leaf axis, compared with the closely related A. hispidus var. hispidus. This anatomical difference may be a general tendency of species to adapt to serpentine environments. However, investigations have only recently been initiated, and the mechanism of adaptation remains unclear.

Adenophora triphylla (Thunb.) A.DC. var. japonica (Regel) H. Hara (Campanulaceae) is distributed throughout Japan, Korea, and Sakhalin. It includes rich morphological variations (Okazaki, 1993), to adapt to different environments. For instance, Yamanaka and Takezaki (1959) reported that stenophyllization, which means the narrowing process of a leaf, of A. triphylla var. japonica occurs in some areas of Kochi Prefecture, Japan. Moreover, Ohga et al. (2012) indicated that the leaf of this rheophytic ecotype was narrower than that of the normal type, because of a decreased number and size of cells. A serpentine ecotype of this species was identified 
by the present workers with narrower leaves and thinner stems (Figure 1 and Figure 2) in some areas of Kochi Prefecture, Japan, where other serpentine taxa such as Aster hispidus var. leptocladus and Scabiosa japonica Miq. are sympatric. Interestingly, the leaf morphology of the serpentine ecotype was similar to that A. triphylla var. japonica, despite the environmental differences between rheophytic and serpentine areas. We performed morphological and anatomical analyses of the leaves, and compared our results with previously published data on the rheophytic ecotype (Ohga et al., 2012).
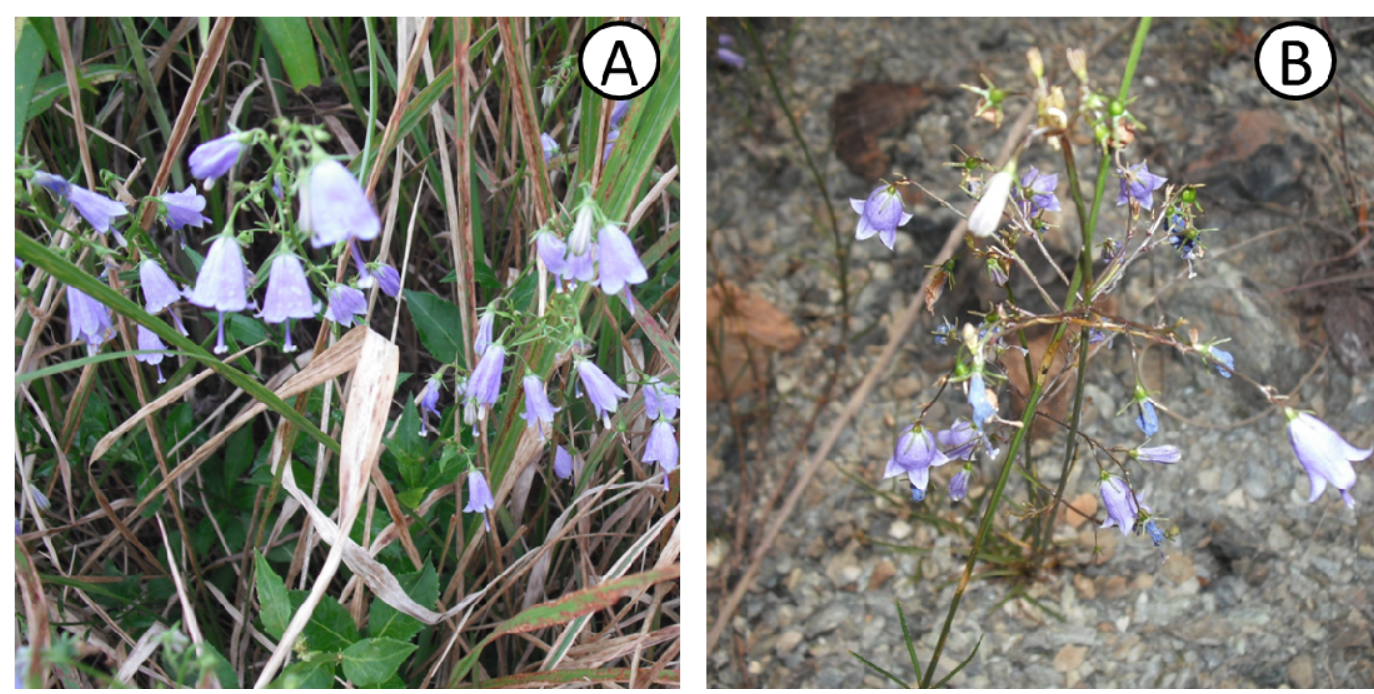

Figure 1. Adenophora triphylla var. japonica

A: Normal type; B: Serpentine ecotype in Shingu.

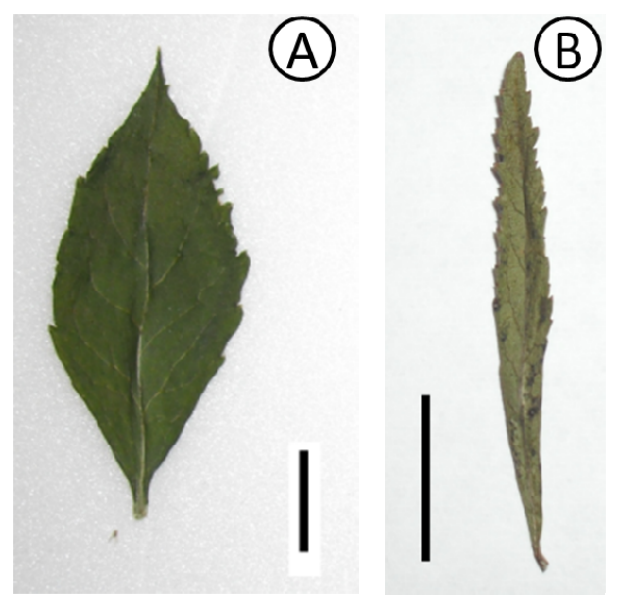

Figure 2. Leaves of Adenophora triphylla var. japonica

A: Normal type; B: Serpentine ecotype in Shingu. Bar $=1 \mathrm{~cm}$.

\section{Materials and Methods}

\subsection{Plant Materials}

All samples of Adenophora triphylla var. japonica examined in this study were collected from fields in 2011. A total of 66 individuals, representing two populations inhabiting serpentine soils (Shingu: Kochi City, Kochi

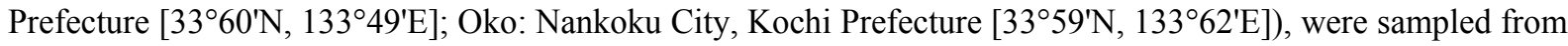
across the species range. 


\subsection{Morphological Analyses}

For morphological analysis, individuals were measured for the following continuous macromorphological variables of leaves: (i) length and width of leaf blade; (ii) thickness of leaf; and (iii) angle of leaf base. Measurements were determined using a digital calliper. Leaf measurements were made from the fully expanded leaf at the middle portion of the plant height. The leaf index values were calculated as the ratio of the leaf length to the leaf width, according to Tsukaya (2002).

\subsection{Anatomical Analyses}

For anatomical analysis, the fully expanded leaves at the middle portion of the plant height were collected from each individual. To count the number of cells on the blade, the leaf surface was peeled off by means of Suzuki's Universal Micro-Printing (SUMP) method (Figure 3). The middle part of the blade along the midrib was analyzed to determine the number and size of adaxial epidermal cells and stomatal numbers. Replicas of each leaf $\left(1 \mathrm{~cm}^{2}\right)$ were made to measure stomatal density. The copied SUMP images were examined twice for each leaf, using a light microscope.

\subsection{Molecular Analyses}

For the molecular analyses, total DNA was isolated from flesh leaves using a Plant Genomic DNA Mini Kit (VIOGENE, Sunnyvale, USA), according to the manufacturer's protocol. After this, we amplified the internal transcribed spacer (ITS) region from nrDNA using primers designed by White et al. (1990). DNA was amplified by PCR in a $50-\mu 1$ reaction volume containing approximately $50 \mathrm{ng}$ total DNA, $10 \mathrm{mM}$ Tris-HCl buffer (pH 8.3) with $50 \mathrm{mM} \mathrm{KCl}$ and $1.5 \mathrm{mM} \mathrm{MgCl}_{2}, 0.2 \mathrm{mM}$ of each dNTP, 1.25 units Taq DNA polymerase (TaKaRa), and 0.5 $\mu \mathrm{M}$ of each primer. We used the following thermal cycle profile for amplification: $1.5 \mathrm{~min}$ at $94{ }^{\circ} \mathrm{C}, 2 \mathrm{~min}$ at $48{ }^{\circ} \mathrm{C}$, and $3 \mathrm{~min}$ at $72{ }^{\circ} \mathrm{C}$, for 45 cycles, followed by a 15 min extension at $72{ }^{\circ} \mathrm{C}$. After amplification, PCR products of the ITS region, were subjected to electrophoresis in $1 \%$ low-melting-temperature agarose gels with the aim to remove by-products and purify the amplified products. We sequenced the purified PCR products using BigDye Terminator ver. 3.1 (Applied BioSystems) and ABI Prism 3100 Genetic Analyzer (Applied BioSystems) according to the manufacturer's instructions. For sequencing, we used the same primers as those used for amplification.

\subsection{Phylogenetic Analyses}

To construct phylogenetic trees, the sequences were aligned using Clustal W (Thompson et al., 1994) with default settings. The positions of insertions and deletions (InDels) were manually determined and excluded the InDels for phylogenetic analysis. To assess the relationships between sequences, we constructed phylogenetic trees from the DNA sequences using Neighbour-joining (NJ), Maximum likelihood (ML), and Bayesian (BI) methods. The best-fit model of sequence evolution was calculated using the Akaike information criterion (AIC) with PAUP 4.0b10 (Swofford, 2002) and Modeltest v3.7 (Posada \& Crandall, 1998). NJ and ML analyses were performed under the best-fit model using PAUP $4.0 \mathrm{~b} 10$ and TreeFinder (Jobb et al., 2004), respectively. For the $\mathrm{NJ}$ and $\mathrm{ML}$ analyses, confidence in tree topology was tested using non-parametric bootstrap analysis (Felsenstein 1985) with 1000 replicates.
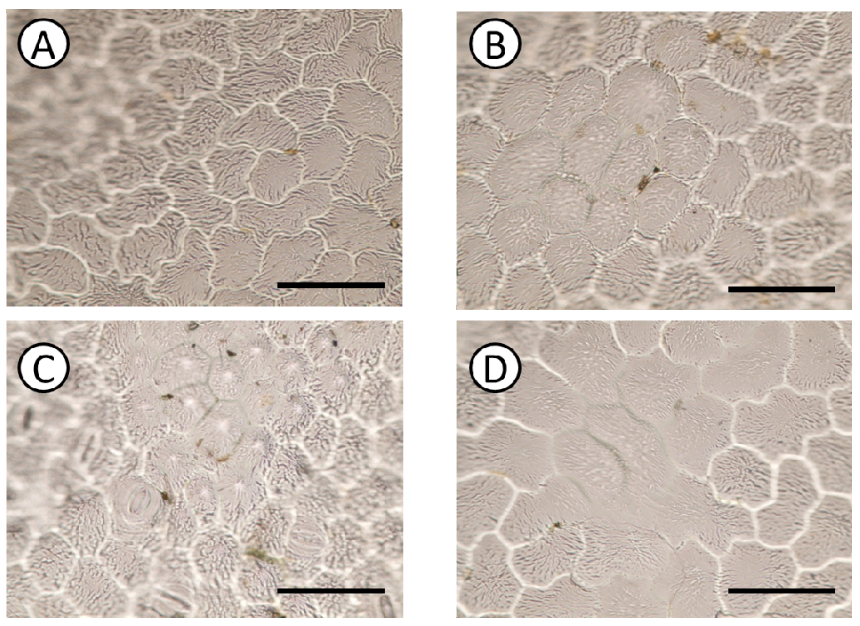

Figure 3. Suzuki's Universal Micro-Printing method (SUMP) replicas of Adenophora triphylla var. japonica A: Higashisako; B: Hitsuzan; C: Shingu; D: Okou. Bar $=100 \mu \mathrm{m}$. 
Table 1. Morphological and anatomical measurements of Adenophora triphylla var. japonica

\begin{tabular}{|c|c|c|c|c|c|c|c|c|c|c|c|c|}
\hline \multirow[b]{2}{*}{ Trait } & \multicolumn{4}{|c|}{ Serpentine } & \multicolumn{4}{|c|}{ Rheophytic $^{1}$} & \multicolumn{4}{|l|}{ Normal $^{1}$} \\
\hline & \multicolumn{2}{|l|}{ Shingu } & \multicolumn{2}{|l|}{ Oko } & \multicolumn{2}{|l|}{$\begin{array}{l}\text { Shimanto } \\
\text { River }\end{array}$} & \multicolumn{2}{|l|}{$\begin{array}{l}\text { Yoshino } \\
\text { River }\end{array}$} & \multicolumn{2}{|c|}{ Higashisako } & \multicolumn{2}{|l|}{ Hitsuzan } \\
\hline Morphological $^{2}$ & & & & & & & & & & & & \\
\hline $\begin{array}{l}\text { Leaf length } \\
(\mathrm{mm})\end{array}$ & $\begin{array}{l}32.6 \pm \\
10.5\end{array}$ & $\mathrm{bc}$ & $\begin{array}{l}33.0 \pm \\
9.8\end{array}$ & $\mathrm{bc}$ & $\begin{array}{l}33.6 \pm \\
10.7\end{array}$ & $\mathrm{~b}$ & $\begin{array}{l}25.8 \pm \\
8.2\end{array}$ & $\mathrm{c}$ & $\begin{array}{l}50.6 \pm \\
9.9\end{array}$ & $\mathrm{a}$ & $\begin{array}{l}39.2 \pm \\
13.2\end{array}$ & $\mathrm{~b}$ \\
\hline $\begin{array}{l}\text { Leaf } \\
(\mathrm{mm})\end{array} \quad$ width & $\begin{array}{l}3.4 \pm \\
1.6\end{array}$ & d & $\begin{array}{l}8.0 \pm \\
3.0\end{array}$ & $\mathrm{c}$ & $\begin{array}{l}6.7 \pm \\
2.2\end{array}$ & $\mathrm{c}$ & $\begin{array}{l}6.5 \pm \\
2.6\end{array}$ & $\mathrm{c}$ & $\begin{array}{ll}17.9 & \pm \\
2.8 & \end{array}$ & $\mathrm{a}$ & $\begin{array}{l}13.1 \pm \\
5.1\end{array}$ & $\mathrm{~b}$ \\
\hline $\begin{array}{l}\text { Leaf } \\
\left(\mathrm{mm}^{2}\right)\end{array} \quad$ size & $\begin{array}{l}53.0 \pm \\
26.4\end{array}$ & $d$ & $\begin{array}{l}139.4 \\
\pm 81.6\end{array}$ & $\mathrm{c}$ & $\begin{array}{l}119.9 \\
\pm 68.6\end{array}$ & $\mathrm{~cd}$ & $\begin{array}{l}91.3 \pm \\
60.7\end{array}$ & $\mathrm{~cd}$ & $\begin{array}{l}457.4 \pm \\
132.1\end{array}$ & $\mathrm{a}$ & $\begin{array}{l}275.4 \pm \\
176.8\end{array}$ & $\mathrm{~b}$ \\
\hline Leaf index ${ }^{3}$ & $\begin{array}{l}12.1 \pm \\
7.1\end{array}$ & $\mathrm{a}$ & $\begin{array}{ll}4.4 & \pm \\
1.7 & \end{array}$ & $\mathrm{bc}$ & $\begin{array}{l}5.2 \pm \\
1.3\end{array}$ & $\mathrm{~b}$ & $\begin{array}{l}4.1 \pm \\
1.0\end{array}$ & $\mathrm{c}$ & $\begin{array}{ll}2.9 & \pm \\
0.6 & \end{array}$ & $\mathrm{~d}$ & $\begin{array}{ll}3.2 & \pm \\
1.1 & \end{array}$ & $\mathrm{~d}$ \\
\hline $\begin{array}{l}\text { Leaf thickness } \\
(\mu \mathrm{m})\end{array}$ & $\begin{array}{l}211.8 \\
\pm 32.0\end{array}$ & $\mathrm{a}$ & $\begin{array}{l}211.7 \\
\pm 31.3\end{array}$ & $\mathrm{a}$ & $\begin{array}{l}163.0 \\
\pm 16.9\end{array}$ & $\mathrm{~b}$ & $\begin{array}{l}173.8 \\
\pm 12.3\end{array}$ & $\mathrm{~b}$ & $\begin{array}{l}211.0 \pm \\
19.0\end{array}$ & $\mathrm{a}$ & $\begin{array}{l}199.6 \pm \\
23.3\end{array}$ & $\mathrm{a}$ \\
\hline $\begin{array}{l}\text { Angle of leaf } \\
\text { base (degrees) }\end{array}$ & $\begin{array}{l}13.5 \pm \\
8.1\end{array}$ & c & $\begin{array}{l}30.1 \pm \\
18.2\end{array}$ & b & $\begin{array}{l}23.8 \pm \\
5.7\end{array}$ & b & $\begin{array}{l}27.0 \pm \\
7.3\end{array}$ & $\mathrm{~b}$ & $\begin{array}{ll}46.1 & \pm \\
10.6 & \end{array}$ & $\mathrm{a}$ & $\begin{array}{ll}46.1 \quad \pm \\
17.5\end{array}$ & $\mathrm{a}$ \\
\hline \multicolumn{13}{|l|}{ Anatomical $^{2}$} \\
\hline $\begin{array}{l}\text { Epidermal cell } \\
\text { length }(\mu \mathrm{m})\end{array}$ & $\begin{array}{l}49.7 \pm \\
6.9\end{array}$ & $\mathrm{~b}$ & $\begin{array}{l}46.6 \pm \\
6.5\end{array}$ & $\mathrm{bc}$ & $\begin{array}{l}41.1 \pm \\
4.9\end{array}$ & $\mathrm{c}$ & $\begin{array}{l}42.4 \pm \\
8.4\end{array}$ & $\mathrm{bc}$ & $\begin{array}{l}56.4 \quad \pm \\
9.3\end{array}$ & $\mathrm{a}$ & $\begin{array}{l}58.8 \quad \pm \\
7.4\end{array}$ & $\mathrm{a}$ \\
\hline $\begin{array}{l}\text { Epidermal cell } \\
\text { width }(\mu \mathrm{m})\end{array}$ & $\begin{array}{l}41.5 \pm \\
6.2\end{array}$ & $\mathrm{~b}$ & $\begin{array}{l}49.5 \pm \\
5.8\end{array}$ & $\mathrm{a}$ & $\begin{array}{l}40.7 \pm \\
5.1\end{array}$ & $\mathrm{~b}$ & $\begin{array}{l}41.4 \pm \\
8.8\end{array}$ & $\mathrm{~b}$ & $\begin{array}{l}48.5 \quad \pm \\
5.8\end{array}$ & $\mathrm{a}$ & $\begin{array}{l}51.2 \quad \pm \\
7.6\end{array}$ & $\mathrm{a}$ \\
\hline $\begin{array}{l}\text { Epidermal cell } \\
\text { size }\left(\mu \mathrm{m}^{2}\right)\end{array}$ & $\begin{array}{l}2037.8 \\
\pm \\
467.0\end{array}$ & $\mathrm{~b}$ & $\begin{array}{l}2265.4 \\
\pm \\
483.1\end{array}$ & $a b$ & $\begin{array}{l}1645.1 \\
\pm \\
502.0\end{array}$ & $\mathrm{c}$ & $\begin{array}{l}1644.5 \\
\pm \\
390.0\end{array}$ & $\mathrm{bc}$ & $\begin{array}{l}2639.7 \\
\pm \\
576.1\end{array}$ & $\mathrm{a}$ & $\begin{array}{l}2912.3 \\
\pm \\
563.3\end{array}$ & $\mathrm{a}$ \\
\hline $\begin{array}{l}\text { Epidermal cell } \\
\text { number in } \\
\text { longitudinal } \\
\text { direction }\end{array}$ & $\begin{array}{l}624 \\
\pm \\
118\end{array}$ & $\mathrm{~b}$ & $\begin{array}{l}844 \\
\pm \\
282\end{array}$ & $\mathrm{a}$ & $\begin{array}{l}881 \\
\pm \\
222\end{array}$ & $\mathrm{a}$ & $\begin{array}{l}717 \\
\pm \\
251\end{array}$ & $a b$ & $\begin{array}{l}783 \\
\pm \\
297\end{array}$ & $\mathrm{ab}$ & $\begin{array}{l}708 \\
\pm \\
267\end{array}$ & $a b$ \\
\hline $\begin{array}{lr}\text { Epidermal cell } \\
\text { number } & \text { in } \\
\text { latitudinal } & \\
\text { direction } & \end{array}$ & $\begin{array}{l}95 \\
\pm \\
37\end{array}$ & $\mathrm{c}$ & $\begin{array}{l}158 \\
\pm \\
48\end{array}$ & $\mathrm{~b}$ & $\begin{array}{l}143 \\
\pm \\
41\end{array}$ & $\mathrm{bc}$ & $\begin{array}{l}142 \\
\pm \\
42\end{array}$ & $\mathrm{bc}$ & $\begin{array}{l}315 \\
\pm \\
63\end{array}$ & $\mathrm{a}$ & $\begin{array}{l}294 \\
\pm \\
132\end{array}$ & $\mathrm{a}$ \\
\hline $\begin{array}{l}\text { Epidermal cell } \\
\text { number }\end{array}$ & $\begin{array}{l}29482 \\
\pm \\
15701\end{array}$ & $\mathrm{~d}$ & $\begin{array}{l}68191 \\
\pm \\
37572\end{array}$ & $\mathrm{c}$ & $\begin{array}{l}66502 \\
\pm \\
26855\end{array}$ & $\mathrm{c}$ & $\begin{array}{l}56000 \\
\pm \\
35954\end{array}$ & $\mathrm{~cd}$ & $\begin{array}{l}141121 \\
\pm \\
56694\end{array}$ & $\mathrm{a}$ & $\begin{array}{l}104530 \\
\pm \\
72320\end{array}$ & $\mathrm{~b}$ \\
\hline $\begin{array}{l}\text { Stomatal } \\
\text { density } \\
\left(\mathrm{N} / \mathrm{mm}^{2}\right)\end{array}$ & $\begin{array}{l}314 \\
\pm \\
46\end{array}$ & $\mathrm{~b}$ & $\begin{array}{l}250 \\
\pm \\
42\end{array}$ & $\mathrm{c}$ & $\begin{array}{l}440 \\
\pm \\
97\end{array}$ & $\mathrm{a}$ & $\begin{array}{l}445 \\
\pm \\
70\end{array}$ & $\mathrm{a}$ & $\begin{array}{l}306 \\
\pm \\
74\end{array}$ & $\mathrm{~b}$ & $\begin{array}{l}257 \\
\pm \\
50\end{array}$ & $\mathrm{c}$ \\
\hline
\end{tabular}

Columns (a, b, c, d) marked by different letters differ significantly according to Tukey's HSD test $(\mathrm{P}<0.05)$.

${ }^{1}$ After Ohga et al. (2012).

${ }^{2}$ All measurements are represented as mean \pm standard deviation.

${ }^{3}$ Nonparametric pairwise comparison was conducted (Steel-Dwass test).

\section{Results}

The leaf morphologies of the two populations of the serpentine ecotype of Adenophora triphylla var. japonica 
are summarized in Table 1. In comparison with the other populations, including the normal and rheophytic, the Shingu population had a significantly smaller mean leaf width and mean angle of leaf base. Additionally, the mean leaf thickness differed significantly between the serpentine and rheophytic ecotypes. Moreover, the mean leaf size differed significantly between the serpentine and normal populations. The leaf index of the Oko population did not differ significantly from that of the rheophytic ecotype. By contrast, the leaf index of the Shingu population was significantly larger than that of the rheophytic ecotype. The mean adaxial epidermal cell size was calculated using the mean epidermal cell length and mean epidermal cell width measured from SUMP samples of the serpentine ecotypes from all of the investigated localities (Table 1). The mean epidermal cell length did not differ significantly between the Shingu and Oko populations. By contrast, the mean epidermal cell width of the Shingu population was significantly smaller than that of the Oko population. Moreover, with the exception of the Oko population, the mean epidermal cell lengths and mean epidermal cell widths of the serpentine and rheophytic ecotypes were significantly smaller than those of the normal populations. The mean epidermal cell number was calculated from the mean leaf size and mean cell size. The mean epidermal cell number of the Shingu population was significantly lower than that of the Oko population. However, there were no significant differences in mean epidermal cell numbers between the serpentine and rheophytic ecotypes. By contrast, the stomatal densities of the serpentine populations were significantly lower than those of the rheophytic.

To reveal the phylogenetic relationship among ecotypes of Adenophora triphylla var. japonica, we conducted phylogenetic analyses of nuclear ITS sequences using ecotypes (serpentine and rheophytic) of this species adding to fifteen previous published sequences of Adenophora species (Figure 4, Table 2 and Table 3). Our phylogenetic trees based on the NJ and ML methods indicated that individuals of $A$. triphylla var. japonica were consisted in a monophyletic group with a high bootstrap value. In addition, there is no sequence substitution among ecotypes of $A$. triphylla var. japonica (serpentine, rheophytic, and normal types).
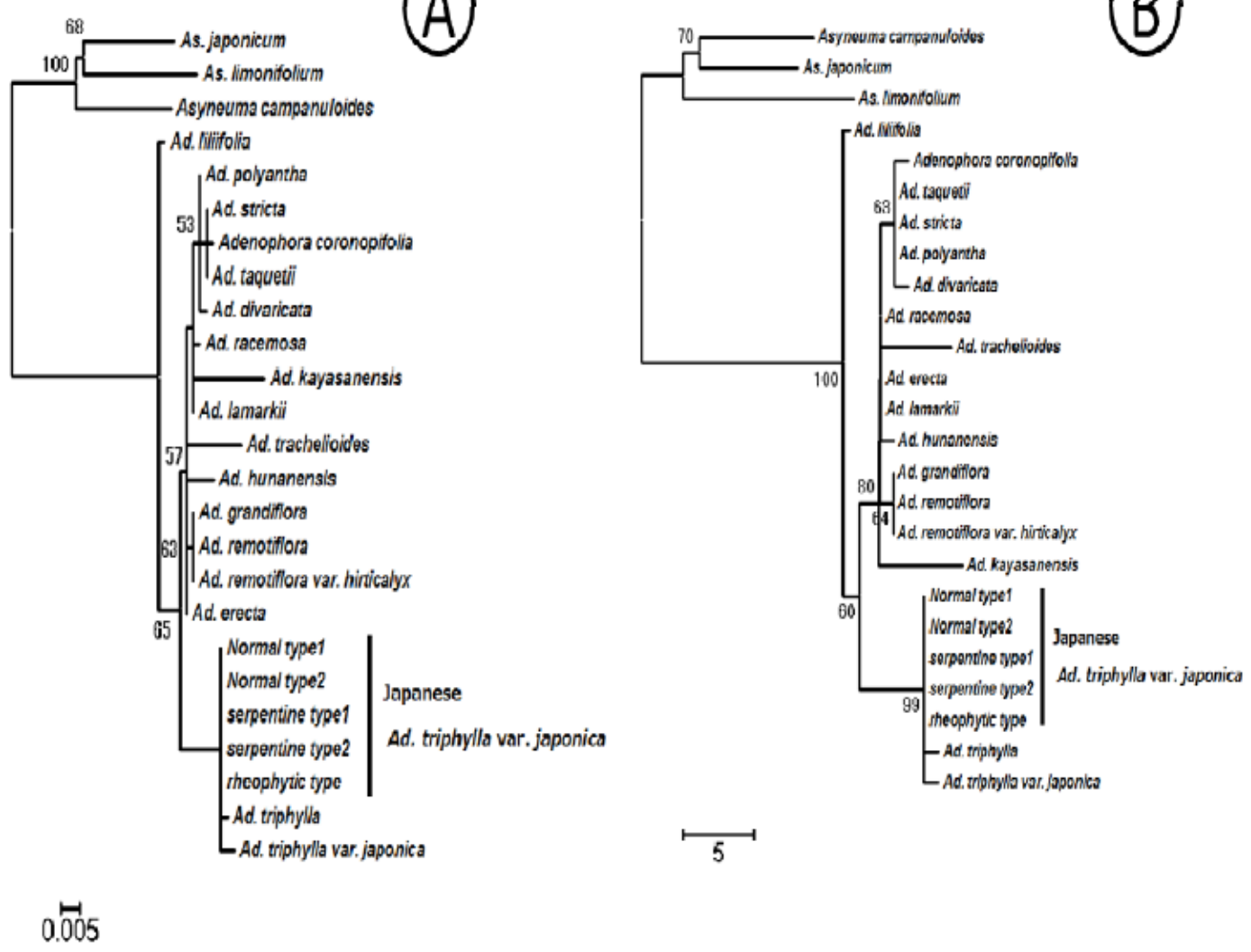

Figure 4. Phylogeny of Adenophora species and Japanese Adenophora triphylla var. japonica based on ITS sequences of nuclear DNA

(A): ML-tree; (B): NJ-tree. Numbers above branches indicate bootstrap value. 
Table 2. Sampling localities used in the phylogenetic analyses

\begin{tabular}{lll}
\hline Locality & OTU name & Accession No. \\
\hline Kochi Prefecture, Konan City, Noichi - Cho, Higashisako & Normal type1 & AB743776 \\
Kochi Prefecture, Muroto City, Murotomisaki-Cho, Cape Muroto-misaki & Normal type2 & AB743779 \\
Kochi Prefecture, Kochi City, Kagamiori, Shingu & serpentine type1 & AB743777 \\
Kochi Prefecture, Kochi City, Ikku & serpentine type2 & AB743778 \\
Tokushima Prefecture, Miyoshi City, Nishiiyayama Village, Yoshino River & rheophytic type & AB743780 \\
\hline
\end{tabular}

Table 3. Adenophora taxa used in the phylogenetic analyses, which, together with the listed database accession numbers of sequences.

\begin{tabular}{lll}
\hline Species name & OTU name & Accession No. \\
\hline Adenophora coronopifolia & Adenophora coronopifolia & HQ704519 \\
Ad. erecta & Ad. erecta & HQ704554 \\
Ad. divaricata & Ad. divaricata & HQ704546 \\
Ad. grandiflora & Ad. grandiflora & HQ704522 \\
Ad. hunanensis & Ad. hunanensis & EU591977 \\
Ad. kayasanensis & Ad. kayasanensis & HQ704523 \\
Ad. polyantha & Ad. polyantha & HQ704524 \\
Ad. lamarkii & Ad. lamarkii & HQ704553 \\
Ad. liliifolia & Ad. liliifolia & DQ304581 \\
Ad. racemosa & Ad. racemosa & HQ704525 \\
Ad. remotiflora & Ad. remotiflora & HQ704526 \\
Ad. remotiflora var. hirticalyx & Ad. remotiflora var. hirticalyx & HQ704528 \\
Ad. stricta & Ad. stricta & HQ704529 \\
Ad. taquetii & Ad. taquetii & HQ704555 \\
Ad. trachelioides & Ad. trachelioides & AY548196 \\
Ad. triphylla & Ad. triphylla & AY548194 \\
Ad. triphylla var. japonica & Ad. triphylla var. japonica & AY548193 \\
Outgroup & & \\
Asyneuma campanuloides & Asyneuma campanuloides & DQ304586 \\
As. japonicum & As. japonicum & HQ704533 \\
As. limonifolium & As. limonifolium & DQ304587 \\
\hline
\end{tabular}

\section{Discussion}

Some populations of plant species that occupy adjacent and contrasting soil environments present distinct advantages for the study of local adaptation. Contrasting edaphic environments can create contrasting selection pressures, while the close proximity of populations increases the opportunity for gene flow. In the present study, the morphological leaf differences between the serpentine and non-serpentine forms of Adenophora triphylla var. japonica are evaluated. Serpentine soils provide a hostile habitat for non-adapted plant populations. Evidence suggests that trait differences potentially involved in serpentine adaptation have diverged between serpentine and non-serpentine ecotypes, as a consequence of consistent directional selection. Based on comparative morphological analyses, Ohga et al. (2012) demonstrated, as expected, that the leaf of the rheophytic ecotype of A. triphylla var. japonica was narrower than that of the normal type. The present results indicate that the leaf morphology of the serpentine ecotype of this species is similar to that of rheophytic ecotype but for the leaf thickness which differs significantly between them (Table 1). Interestingly, a decrease in the number and size of 
leaf cells contributed to the stenophyllization process in both (Table 1). Moreover, the adaptation in serpentine soils seems to occur in short time because of no nucleotide polymorphism in A. triphylla var. japonica of Japan (Figure 4). Altogether, these findings suggest that similar stenophyllization processes exist, but that each ecotype is adapted to different conditions of riverside and serpentine environments. Furthermore, the leaf thickness and stomatal density differed significantly between the serpentine and rheophytic ecotypes, but not between the serpentine and normal types (Table 1). Thus, it appears that the rheophytic ecotype possesses additional adaptation to solar radiation and evaporation in riverside areas.

Members of Campanulaceae, including A. triphylla var. japonica, are located at the ancestral position of Asteraceae, and belong to Asterales (Soltis et al., 1999). The anatomical study of the serpentine plant, Aster hispidus var. leptocladus indicated that the leaf morphology was differentiated in terms of number and size of cells (Hayakawa et al., 2012). Moreover, the stenophyllization process in the leaves of the rheophytic plants Dendranthema yoshinaganthum (Makino ex Kitam.) Kitam. (Tsukaya, 2002) and Aster ovatus var. ripensis (Makino) Mot.Ito and Soejima (Aster microcephalus var. ripensis Makino - Yamada et al., 2011) was derived from the similar processes. These findings suggest that adaptation to serpentine and rheophytic environments involves stenophyllization with regard to the number and size of cells in a leaf. Thus, this process appears to be a general tendency in members of the Asterales.

To summarize, the existence of stenophyllization in the leaf of the serpentine ecotype of A. triphylla var. japonica is demonstrated. However, the leaf index differed significantly between the two investigated serpentine areas. Hayakawa et al. (2012) observed that the leaf index of the serpentine species, Aster hispidus var. leptocladus, differed according to serpentine areas, and proposed that leaf morphology was involved not only in stenophyllization, but also in minitualization. Such minitualized leaves exist in the serpentine ecotype of $A$. triphylla var. japonica.

\section{Acknowledgements}

We thank Dr K. Matsuyama, Dr Y. Yoshimi, Dr N. Yokoyama, Dr S. Isomoto, Dr H. Miyata, Dr Y. Tsuchiya, Dr S. Takei, Dr T. Sunami, Dr N. Kakimoto, and Dr Y. Kumekawa for help during our research. This study was partly supported by the River Fund managed by the Foundation of River and Watershed Environment Management (FOREM), Japan, and a Grant-in-Aid for Scientific Research from the Ministry of Education, Science and Culture of Japan (to TF).

\section{References}

Brady, K. U., Kruckeberg, A. R., \& Bradshaw, H. D. Jr. (2005). Evolutionary ecology of plant adaptation to serpentine soils. Annual Review in Ecology, Evolution, and Systematics, 36, 243-266. $\mathrm{http}: / / \mathrm{dx}$.doi.org/10.1146/annurev.ecolsys.35.021103.105730

Felsenstein, J. (1985). Confidence limits on phylogenies: an approach using the bootstrap. Evolution, 39(4), 783-791. http://dx.doi.org/10.2307/2408678

Hayakawa, H., Tunala., Minamiya, Y., Gale, S. W., Yokoyama, J., Ito, K., Arakawa, R., \& Fukuda, T. (2012). Comparative study of leaf morphology in Aster hispidus Thunb. var. leptocladus (Makino) Okuyama (Asteraceae). American Journal of Plant Science, 3(1), 110-113. http://dx.doi.org/10.4236/ajps.2012.31011

Jobb, G., von Haeseler, A., \& Strimmer, K. (2004). TREEFINDER: a powerful graphical analysis environment for molecular phylogenetics. BMC Evolutionary Biology, 4, 18. http://dx.doi.org/10.1186/1471-2148-4-18

Kruckeberg, A. R. (1951). Intraspecific variability in the response of certain native plant species to serpentine soil. American Journal of Botany, 38(6), 408-419. http://dx.doi.org/10.2307/2438248

Kruckeberg, A. R. (1954). The ecology of serpentine soils III. Plant species in relation to serpentine soils. Ecology, 35(2), 267-274.

Kruckeberg, A. R. (1967). Ecotypic response to ultramafic soils by some plant species of northwestern United States. Brittonia, 19(2), 133-144. http://dx.doi.org/10.2307/2805271

Ohga, K., Muroi, M., Hayakawa, H., Ito, K., Yokoyama, J., Tebayashi, S., ... Fukuda, T. (2012). Comparative morphology and anatomy of non-rheophytic and rheophytic types of Adenophora triphylla var. japonica (Campanulaceae). American Journal of Plant Science, 3(6), 805-809. http://dx.doi.org/10.4236/ajps.2012.36097

Okazaki, J. (1993). Adenophora Fisch. In: Iwatsuki, K., Yamazaki, T., David, E. B. and Ohba, H. (eds.) Flora of Japan Volume IIIa. Angiospermae Dicotyledoneae Sympetalae (a) (pp. 406-410). Kodansha, Tokyo. 
Posada, D., \& Crandall, K. A. (1998). MODELTEST: testing the model of DNA substitution. Bioinformatics, 14(9), 817-818. http://dx.doi.org/10.1093/bioinformatics/14.9.817

Rajakaruna, N., Siddiqi, M. Y., Whitton, J., Bohm, B. A., \& Glass, A. D. M. (2003). Differential responses to $\mathrm{Na}^{+} / \mathrm{K}^{+}$and $\mathrm{Ca}^{2+} / \mathrm{Mg}^{2+}$ in two edaphic races of the Lasthenia californica (Asteraceae) complex: a case for parallel evolution of physiological traits. New Phytologist, 157(1), 93-103. http://dx.doi.org/10.1046/j.1469-8137.2003.00648.x

Soltis, P. S., Soltis, D. E., \& Chase, M. W. (1999). Angiosperm phylogeny inferred from multiple genes as a tool for comparative biology. Nature, 402. 402-404. http://dx.doi.org/10.1038/46528

Swofford, D. L. (2002). PAUP*. Phylogenetic Analysis Using Parsimony (*and Other Methods). Version 4. Sinauer Associates, Sunderland MA.

Thompson, J. D., Higgins, D. G., \& Gibson, T. J. (1994). CLUSTAL W: improving the sensitivity of progressive multiple sequence alignment through sequence weighting, position-specific gap penalties and weight matrix choice. Nucleic Acids Research, 22(22), 4673-4680. http://dx.doi.org/10.1093/nar/22.22.4673

Tsukaya, H. (2002). Leaf anatomy of a rheophyte, Dendranthema yoshinaganthum (Asteraceae), and of hybrids between D. yoshinaganthum and a closely related non-rheophyte, D. indicum. Journal of Plant Research, 115(5), 329-333. http://dx.doi.org/10.1007/s10265-002-0041-y

White, T. J., Bruns, T., Lee, S., \& Taylor, J. (1990). Amplification and direct sequencing of fungal ribosomal RNA genes for phylogenetics. In: Innis M., Gelfand D., Sninsky J., White T. J. (eds.) PCR protocols: a guide to methods and application (pp. 315-322). Academic Press, San Diego.

Wright, J. W., Stanton, M. L., \& Scherson, R. (2006). Local adaptation to serpentine and non-serpentine soils in Collinsia sparsiflora. Evolutionary Ecology Research, 8, 1-21.

Yamada, Y., Hayakawa, H., Minamiya, Y., Ito, K., Shibayama, Z., Arakawa, R., \& Fukuda, T. (2011). Comparative morphology and anatomy of rheophytic Aster microcephalus (Miq.) Franch. et Sav. var. ripensis Makino (Asteraceae). Journal of Phytogeography and Taxonomy, 59(1), 35-42.

Yamanaka, T, \& Takezaki, K. (1959). Distribution and ecology of Rhododendron ripense Makino, with reference to the vegetation and flora on rocky river-bank. The Journal of Japanese Botany, 34, 215-224 (in Japanese). 